\title{
STUDI KELAYAKAN PEMANFAATAN LIMBAH SUMPIT UNTUK PEMBUATAN PRODUK PENGISI RONGGA - RONGGA KERTAS PADA UD MUTIARA 9 SERANG BANTEN
}

\author{
Eka Angkasa Putra Agni Hermawan \\ Management Department FEB UMM \\ E-mail: angkasa.e@gmail.com
}

\begin{abstract}
This study aims to analyse levels of the feasiblity of the utilization of chopstick waste of the manufacture of filler products cavities. To measure the feasibility some aspects should be considered such as market, marketing, operational, human resources, and financial aspect. The result indicated that all acpect was feasible. The market aspect is feasible because it has high demand. Operation aspect is feasible because of modern technology used. Human resource aspects is feasible because of the there were skills labor own by the company, and financial aspect is also feasible because NPV more than zero and payback period less than estimated period.
\end{abstract}

Keyword: waste a feasibility study, UKM, bussiness environment

\section{PENDAHULUAN}

Di daerah pegunungan, khususnya di daerah Banten mulai dari Kabupaten Pandeglang, Kabupaten Malimping, dan Kabupaten Rangkas masih banyak ditemukan tanaman bambu. Hal ini dilihat oleh sebagai orang sebagai peluang bisnis dengan memanfaatkan tanaman bambu. Dari kegiatan produksi yang dilakukan oleh industri kerajinan bambu banyak sekali menghasilkan limbah, terutama pada perusahaan penghasil sumpit.

Proses pembuatan sumpit yang sangat panjang, mulai dari pemotongan bambu menjadi ukuran $20 \mathrm{~cm}$, kemudian dibelah menjadi beberapa bagian, kemudian diserut menjadi bulat-bulat hingga proses akhir yaitu peruncingan. Dari proses yang sangat panjang tersebut banyak menghasilkan limbah, baik berupa serbuk bambu atau serat bambu.
Limbah dari industri pengolahan sumpit jarang sekali ada yang memanfaatkan menjadi sesuatu yang lebih efektif dan bernilai lebih bagi perusahaan. Kenyataan di lapangan bahwa perusahaanperusahaan yang bergerak dibidang yang sama, hanya mengelola limbah tersebut dengan cara membakar atau membuangnya begitu saja, dengan begitu perusahaan harus mengeluarkan biaya lebih untuk melakukan pembuangan limbah tersebut.

Salah satu alternatif dalam pembuatan produk yang berbahan dasar limbah bambu adalah pengisi rongga-rongga kertas, pengisi rongga kertas merupakan alat bantu yang digunakan oleh industri pembuatan kertas disalah satu aktifitas produksinya, yaitu pada saat kertas dileburkan menjadi bubur kertas. 
Untuk merealisasikan pembuatan produk pengisi rongga kertas perlu adanya analisa mengenai tingkat kelayakan dari berbagai aspek.

Dengan demikian perumusan masalah dalam penelitian adalah apakah pemanfaatan limbah sumpit untuk pembuatan produk pengisi rongga-rongga kertas layak dilakukan oleh UD. Mutiara 9 Serang-Banten ?

Adapun tujuan penelitiannya adalah Menganalisis tingkat kelayakan pemanfaatan limbah sumpit untuk pembuatan produk pengisi ronggarongga kertas pada UD. Mutiara 9 Serang-Banten.

\section{TINJAUAN PUSTAKA}

Penelitian yang dilakukan Fronthea Swastawati (2011) dengan judul Studi Kelayakan Dan Efisiensi Usaha Pengasapan Ikan Dengan Asap Cair Limbah Pertanian. Hasil dari penelitian ini adalah produksi cairan asap limbah pertanian dan ikan asap dengan menggunakan cairan asap limbah pertanian yang seperti itu menghasilkan kelayakan produk, keamanan produk dan dapat diterima oleh konsumen dan juga menguntungkan.

Menurut Kasmir dan Jakfar (2012), study kelayakan merupakan penelitian yang dilakukan secara mendalam untuk menentukan apakah usaha yang akan dijalankan memberikan manfaat yang lebih besar dibandingkan dengan biaya yang akan dikeluarkan. Layak disini juga diartikan akan memberikan keuntungan tidak hanya bagi perusahaan yang menjalankannya. Akan tetapi investor, kreditor, pemerintah dan masyarakat luas.

Aspek-aspek dalam Study Kelayakan Bisnis Aspek yang terdapat pada study kelayakan bisnis yang akan dibangun terdiri dari berbagai aspek, mulai dari aspek hukum, aspek sosial dan budaya, aspek pasar dan pemasaran, aspek teknis dan teknologi, aspek manajemen dan aspek keuangan. Agus Sucipto (2010).

Kajian yang dilakukan dalam aspek pasar dan pemasaran bertujuan untuk menguji serta menilai sejauh mana pemasaran dari hasil produk yang dihasilkan perusahaan dapat mendukung pengembangan usaha atau bisnis yang dilakukan. Kajian aspek pasar berkaitan dengan ada tidaknya potensi pasar dan peluang pasar atas suatu produk yang akan diluncurkan dimasa yang akan datang serta berapa market share yang dapat diserap oleh usaha yang akan diproyeksikan dari keseluruhan pasar potensial. Kajian aspek pemasaran bekaitan dengan bagaimana penerapan strategi pemasaran dalam rangka meraih sebagian besar pasar potensial atau peluang pasar yang ada. Dengan kata lain seberapa besar market share (pangsa pasar) yang ditentukan dapat diraih sangat bergantung pada penerapan strategi pemasaran yang dipilih.

Potensi pasar adalah peluang penjualan optimum yang dapat dicapai oleh seluruh penjualan baik saat ini maupun pada masa yang akan datang. Untuk peramalan permintaan yang digunakan dalam peramalan dimasa yang akan datang. Salah satu metode yang dapat digunakan yaitu metode time series dan ekstrapolasi trend. Sedangkan untuk memenangkan persaingan didalam kelompok industri, perusahaan harus memiliki keunggulan kompetitif.

Aspek Operasi bertujuan untuk melihat bagaimana untuk mendukung 
aspek pasar supaya target tercapai. Melalui pemilihan tekhnologi yang baik, proyeksi pengadaan bahan baku yang tepat, dan perencanaan tata letak. Pemilihan jenis teknologi dan peralatan produksi harus dikaitkan dengan kapasitas ekonomis produksi. Siswanto Sutojo (2002). Sedangkanv kelangsungan pasokan bahan baku, bahan pembantu dan bahan pendukung operasi (utilities) seperti listrik, bahan bakar, air, kemasan dan suku cadang, dalam jumlah mutu, jadwal pengadaan dan tingkat harga tertentu, mempunyai peranan penting dalam kelangsungan kegiatan produksi. Siswanto Sutojo (2002).

Tata letak memiliki banyak dampak strategis karena tata letak menentukan daya saing perusahaan dalam hal kapasitas, proses fleksibilitas, dan biaya, serta kualitas lingkungan kerja, kontak pelanggan, dan citra perusahaan.

Aspek Sumber Daya Manusia betujuan untuk melihat bagaimana ketersedian tenaga kerja yang akan diproyeksikan untuk aktivitas produksi, antara lain sebagai berikut:

Analisa Pekerjaan merupakan proses pengumpulan dan pemeriksaan atas aktivitas kerja pokok serta kualifikasi pekerjaan seperti keahlian, pengetahuan, kemampuan, pengalaman. 2) Rekrutmen SDM merupakan kegiatan mencari dan menarik para pelamar pekerjaan dengan motivasi kemampuan, keahlian, dan pengetahuan sumber daya manusia yang diperlukan organisasi untuk mengisi lowongan kerja yang diidentifikasi sebelumnya didalam renacana kepegawaian.

Selanjutnya pada poin 3) Seleksi SDM adalah proses pemilihan orang-orang yang meiliki kualifikasi yang dibutuhkan untuk mengisi lowongan pekerjaan dioganisasi. 4) penetapan Jumlah Karyawan terdapat 2 (dua) metode, yaitu: Metode non ilmiah, yaitu dalam menentukan jumlah karyawan hanya berdasarkan perkiraan - perkiraan saja dan Metode ilmiah, yaitu dalam menentukan jumlah karyawan berdasarkan perhitungan dan analisa beban kerja (work load analysis) serta standard prestasi kerja.

Selanjutnya pada poin 5) Pelatihan Proses sistematis pengubahan perilaku para karyawan untuk meningkatkan keterampilan sesuai dengan tujuan organisasi. Aspek Keuangan bertujuan untuk melihat sumber modal, arus kas dan penilaian investasi melalui NPV dan Payback Period. Perolehan dana dapat dicari dari bebagai sumber dana yang ada sepeti dari modal sendiri atau modal pinjaman atau keduanya. Investasi dilakukan dalam berbagai bentuk digunakan untuk membeli asetaset yang dibutuhkan dalam usaha tersebut. Cash flow menunjukkan berapa uang yang masuk (cash in) ke perusahaan dan jenis-jenis pemasukan tersebut. Cash flow juga menggambarkan berapa uang yang keluar (cash out) serta jenis-jenis biaya yang dikeluarkan.

Adapun kriteria atau teknik yang digunakan untuk menentukan kelayakan suatu usaha atau investasi antara lain: Average Rete of Return (ARR), Payback Periode (PP), Net Present Value (NPV), Internal Rate of Return (IRR), dan Probabilitas Index (PI) atau Benefit and Cost Ratio (B/C Ratio) Berdasarkan teori-teori diatas, dapat disusun kerangka pikir sebagai berikut: 


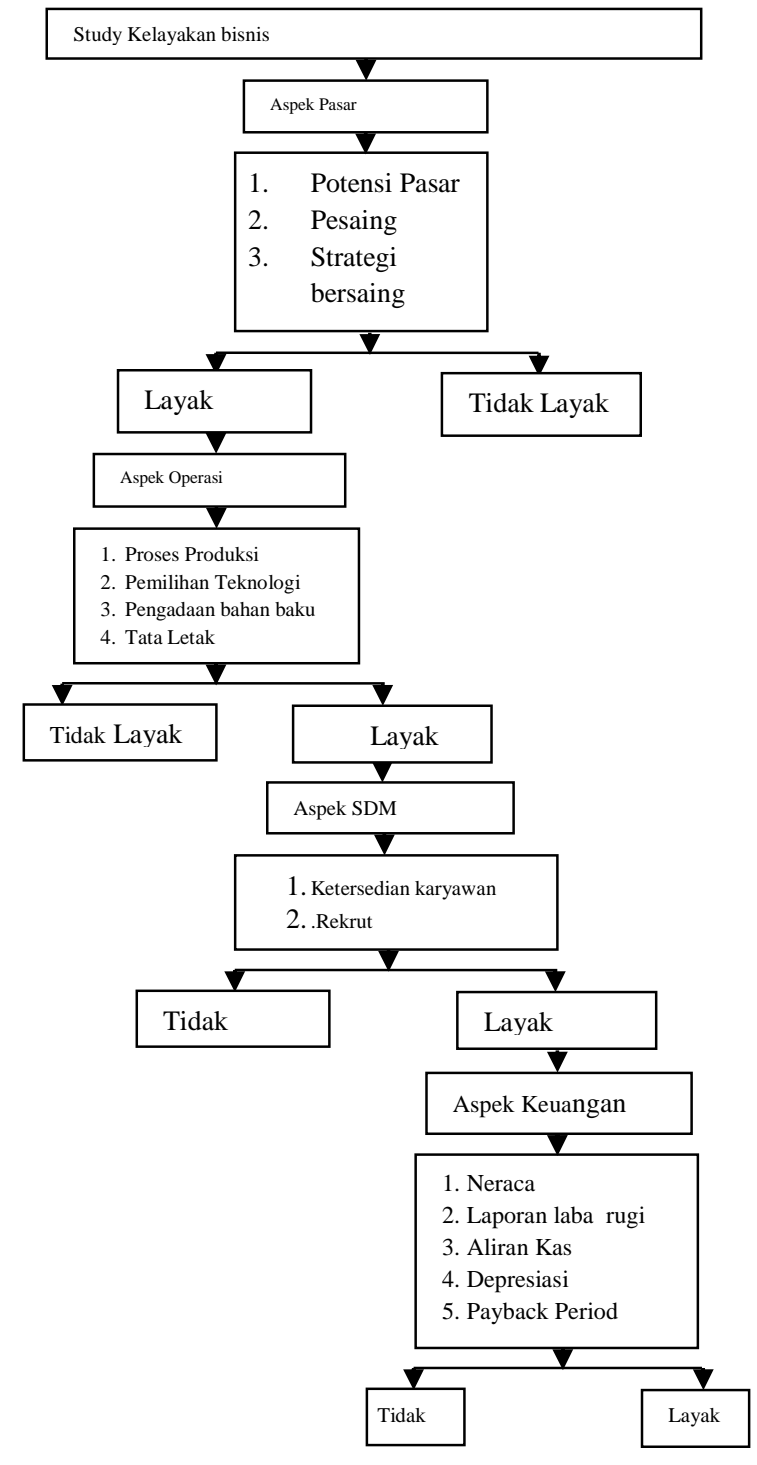

\section{METODE PENELITIAN}

Lokasi penelitian dilakukan di perusahaan sumpit UD. MUTIARA 9 yang berlokasi tepat di Kampung Angsoka Jaya, RT.001 / RW.009, Kelurahan Kasemen Kecamatan Kasemen, Kota Madya Serang Banten.

\section{HASIL PENELITIAN DAN PEMBAHASAN}

Berdasarkan penelitian didapatkan hasil dari analisa aspek pasar dan pemasaran, aspek operasi, aspek sumber daya manusia dan aspek keuangan. Aspek Pasar dan Pemasaran, untuk membuat pengisi rongga kertas permintaan berasal dari PT. X, PT. Indah Kiat (Tanggerang), PT. Fajar Surya Wisesa (Jakarta). Perusahaan-perusahaan di atas membutuhkan pengisi rongga kertas sebesar $5 \%$ dari kapasitas produksinya.

Tabel 1. Permintaan Produk Pengisi

\begin{tabular}{cc}
\multicolumn{2}{c}{ Rongga Kertas } \\
\hline Tahun & Kebutuhan (ton) \\
\hline 2015 & 358.240 \\
2016 & 376.780 \\
2017 & 395.320 \\
2018 & 413.860 \\
2019 & 432.400 \\
\hline
\end{tabular}

Jumlah kebutuhan pengisi rongga kertas setiap tahun mengalami peningkatan kebutuhan bahan pengisi rongga kertas dikarenakan faktor produksi kertas yang ikut mengalami penigkatan setiap tahun.

Pesaing utama dalam pembuatan produk pengisi rongga kertas berasal dari PT. Y yang berlokasi di Negara Thailand, perusahaan tersebut merupakan supplier tunggal bahan pengisi rongga kertas ke PT. X melalui jalur laut antar Negara. Strategi bersaings yang diproyeksikan untuk memasuki pasar yaitu kepemimpinan biaya. Kepemimpinan biaya dalam proyeksi binis yang akan dijalankan mulai dari bahan baku, biaya transportasi hingga harga jual produk.

Aspek Operasi dalam Pemilihan Tekhnologi, teknologi yang akan digunakan dalam proses pembuatan produk pengisi rongga kertas oleh UD. Mutiara 9. Teknologi yang dipilih untuk proyeksi pembuatan produk pengisi rongga 
Tabel 2. Daftar mesin yang digunakan dalam proses produksi

\begin{tabular}{clc}
\hline No & \multicolumn{1}{c}{ Peralatan } & Jumlah \\
\hline 1 & Mesin Conveyor & 1 \\
& Pendek & \\
2 & Mesin Conveyor & 4 \\
& Panjang & \\
3 & Mesin Chipper & 1 \\
4 & Mesin Hummer Mill & 1 \\
5 & Mesin Crusher & 1 \\
6 & Mesin Vibrator & 1 \\
& Screen & \\
7 & Mesin Blower & 1 \\
8 & Mesin Silo & 1 \\
9 & Mesin Dust Collector & 1 \\
\hline
\end{tabular}

kertas berdasarkan kriteria yang telah ditentukan yaitu ketersediaan pemasok mesin yang akan digunakan, tersedianya suku cadang mesin, kapasitas produksi yang sesuai dengan kapasitas limbah yang akan diproduksi dan terakhir mengenai kualitas dan umur ekonomis mesin.

Perencanaan Bahan Baku Perkebunan dan hutan bambu yang berada di daerah Banten memiliki luas \pm 30.000 ha (komunitas bambu), Untuk hutan tanaman kayu di Provinsi Banten terdiri dari hutan jati, sengon, durian, tangkil, acacia, dan mahoni dengan luas 332.152,59 ha.

Perencanaan Tata Letak UD. Mutiara 9 memiliki luas tanah $2300 \mathrm{~m}^{2}$ dengan luas bangunan untuk proses produksi pembuatan sumpit seluas $1700 \mathrm{~m}^{2}$, maka luas tanah yang masih tersisa yaitu seluas $600 \mathrm{~m}^{2}$. Lay out yang diproyeksikan dalam syudi kelayakan usaha ini adalah lay out produk bentuk U.

Aspek Sumber Daya Manusia Hari yang akan digunakan untuk melaksanakan aktivitas produksi pengisi rongga kertas dari hari senin sampai hari sabtu dengan sistem shift.
Kapasitas produksi sebesar 152.4 ton, maka dengan menggunakan 1 mesin dengan menggunakan sistem 3 shift maka diperoleh hasil produksi bisa mencapai 156 ton per bulan.

Asal Tenaga Kerja,Tenaga kerja yang direkrut dengan cara memberdayakan masyarakat sekitar yang memenuhi kriteria untuk mengoperasikan mesin-mesin produksi Untuk prosedur dalam seleksi terdapat sesi wawancara yang meliputi tingkat keahlian dan pengalaman dalam bekerja. Pelatihan difokuskan hanya pada pengoprasian mesin-mesin yang akan digunakan, trainer diambil dari PT.X.

Aspek Keuangan, Biaya Investasi merupakan keseluruhan biaya investasi yang diidentifikasikan dan dihitung secara keseluruhan, Investasi yang dibutuhkan oleh UD. Mutiara 9 dalam perencanaan pengembangan produk baru pembuatan pengisi rongga kertas sebesar Rp.1.371.780.000. Biaya Produksi yaitu keseluruhan dari biaya produksi yang diidentifikasikan dihitung menurut periode waktu atau tahun dimana dilaksanakan proses produksi.

Biaya keseluruhan dari produksi selama periode proyeksi yang dibutuhkan, dari tahun ke tahun mengalami peningkatan dikarenakan faktor inflasi sebesar $7 \%$ setiap tahunnya sehingga biaya produksi ikut mengalami peningkatan.

Biaya

Operasional, Keseluruhan biaya operasional yang diidentifikasikan dihitung menerut periode waktu atau dimana dilaksanakan proses produksi. Adapun biaya Operasional tiap tahun yang diproyeksikan seperti yang tertera pada tabel 4. 
Tabel 3. Total biaya produksi pertahun

\begin{tabular}{cccc}
\hline $\begin{array}{c}\text { Periode waktu } \\
\text { proyeksi }\end{array}$ & Biaya bahan baku & Biaya tenaga kerja & Biaya listrik \\
\hline 2015 & Rp. 54.864.000 & Rp. 496.800.000 & Rp. 339.177.034 \\
2016 & Rp. 58.704.480 & Rp. 531.576.000 & Rp. 362.919.427 \\
2017 & Rp. 62.813.794 & Rp. 568.786.320 & Rp. 388.323.786 \\
2018 & Rp. 67.210.759 & Rp. 608.601.362 & Rp. 415.506.452 \\
2019 & Rp. 71.915.513 & Rp. 651.203.457 & Rp. 444.591.904 \\
\hline
\end{tabular}

Tabel 4. Jumlah Biaya Operasional

\begin{tabular}{lrrrrr}
\hline $\begin{array}{l}\text { Total tiap-tiap tahun } \\
\text { Biaya Oprasional }\end{array}$ & \multicolumn{2}{c}{2015} & \multicolumn{2}{c}{2016} & \multicolumn{2}{c}{2017} & \multicolumn{2}{c}{2018} & \multicolumn{1}{c}{2019} \\
\hline Biaya sewa tempat & 15.000 .000 & 15.000 .000 & 15.000 .000 & 15.000 .000 & 15.000 .000 \\
Biaya perencanaan sdm & 10.000 .000 & 10.000 .000 & 10.000 .000 & 10.000 .000 & 10.000 .000 \\
Bunga Investor & 75.000 .000 & 75.000 .000 & 75.000 .000 & 75.000 .000 & 75.000 .000 \\
Biaya Transportasi & 140.000 & 149.800 & 160.286 & 171.506 & 183.511 \\
Depresiasi Kendaraan & 60.000 .000 & 60.000 .000 & 60.000 .000 & 60.000 .000 & 60.000 .000 \\
Depresiasi perlengkapan & 1.744 .000 & 1.744 .000 & 1.744 .000 & 1.744 .000 & 1.744 .000 \\
Depresiasi Mesin & 59.040 .000 & 59.040 .000 & 59.040 .000 & 59.040 .000 & 59.040 .000 \\
Biaya Administrasi & 8.000 .000 & 8.000 .000 & 8.000 .000 & 8.000 .000 & 8.000 .000 \\
Biaya pemeliharaan & 160.000 .000 & 171.200 .000 & 183.184 .000 & 196.006 .880 & 209.727 .362 \\
Biaya Lain-lain & 5.000 .000 & 5.000 .000 & 5.000 .000 & 5.000 .000 & 5.000 .000 \\
Bonus Karyawan & 41.400 .000 & 44.298 .000 & 47.399 .000 & 50.717 .000 & 54.267 .000 \\
Total & 435.324 .000 & 449.431 .800 & 464.527 .286 & 480.679 .386 & $497 . .961 .873$ \\
\hline
\end{tabular}

Tabel 5. Proyeksi penerimaan produk pengisi rongga kertas dalam setahun

\begin{tabular}{cccc}
\hline Tahun & Jumlah (ton) & Harga Satuan & Total Harga \\
\hline 2015 & 1240 & Rp. 3.600.000 & Rp. 4.464.000.000 \\
2016 & 1400 & Rp. 3.852.000 & Rp. 5.392.800.000 \\
2017 & 1554 & Rp. 4.121.640 & Rp. 6.405.028.000 \\
2018 & 1554 & Rp. 4.410.159 & Rp. 6.853.387.000 \\
2019 & 1554 & Rp. 4.718.870 & Rp. 7.333.123.000 \\
\hline
\end{tabular}

Proyeksi Penerimaan Proyeksi penerimaan dari produk pengisi rongga kertas diestimasi dengan acuan target penjualan mencapai 182 ton dalam setahun. Proyeksi penerimaan dari produk pengisi rongga kertas dapat dilihat pada table 5 .

Pada tahun 2015 diasumsikan hasil produksi hanya $80 \%$ dikarenakan masa penjajakan mesin dan sumber daya manusia, tahun ke dua menigkat menjadi $90 \%$ karena sumber daya manusia mulai memahami pekerjaan dan mesin dan Tahun selanjutnya kapasitas optimum. Proyeksi Aliran Kas (Cash Flow) dapat memberikan informasi mengenai jumlah kas yang diperlukan dalam memulai suatu usaha, perencanaan investasi, dan menjamin kesesuaian kas untuk ketersediaan kas 
terhadap pengeluaran-pengeluaran yang dikeluarkan dimasa yang akan datang.Proyeksi aliran kas seperti yang tertera pada tabel 6 .

Tabel 6. Proyeksi laporan arus kas per 31 Desember

\begin{tabular}{|c|c|c|c|c|c|c|}
\hline $\begin{array}{c}\text { Cash in } \\
\text { flow }\end{array}$ & & 2015 & 2016 & 2017 & 2018 & 2019 \\
\hline & $\begin{array}{l}\text { Laba sesudah } \\
\text { pajak }\end{array}$ & 2.213 .877 .534 & 2.957 .456 .248 & 3.769 .656 .986 & 4.067 .458 .374 & 4.386 .099 .618 \\
\hline & $\begin{array}{l}\text { Depresiasi } \\
\text { kendaraan }\end{array}$ & 60.000 .000 & 60.000 .000 & 60.000 .000 & 60.000 .000 & 60.000 .000 \\
\hline & $\begin{array}{l}\text { Depresiasi } \\
\text { perlengkapan }\end{array}$ & 1.744 .000 & 1.744 .000 & 1.744 .000 & 1.744 .000 & 1.744 .000 \\
\hline & $\begin{array}{l}\text { Depresiasi } \\
\text { mesin }\end{array}$ & 59.040 .000 & 59.040 .000 & 59.040 .000 & 59.040 .000 & 59.040 .000 \\
\hline $\begin{array}{l}\text { Total } \\
\text { Cash In } \\
\text { Flow }\end{array}$ & & 2.093.093.534 & 2.836.672.248 & 3.648 .872 .986 & 3.946 .674 .374 & 4.265.315.618 \\
\hline $\begin{array}{l}\text { Total } \\
\text { Cash Out } \\
\text { Flow }\end{array}$ & Cicilan Utang & $\begin{array}{l}100.000 .000 \\
100.000 .000\end{array}$ & $\begin{array}{l}100.000 .000 \\
100.000 .000\end{array}$ & $\begin{array}{l}100.000 .000 \\
100.000 .000\end{array}$ & $\begin{array}{l}100.000 .000 \\
100.000 .000\end{array}$ & $\begin{array}{l}100.000 .000 \\
100.000 .000\end{array}$ \\
\hline $\begin{array}{l}\text { Net Cash } \\
\text { Flow }\end{array}$ & & 1.993.093.534 & 2.736.672.248 & 3.673 .872 .986 & 3.846 .674 .374 & 4.165.315.618 \\
\hline
\end{tabular}

Proyeksi Payback Period Kumulatif

Modal Rp. 2.000.000.000

Net Cash Flow 1 Rp.1.993.093.534 1.993.093.534

Net Cash Flow 2 Rp.2.736.672.248 4.729.765.782

Net Cash Flow 3 Rp.3.673.872.986 8.403.638.768

Net Cash Flow 4 Rp.3.846.674.374 12.250.311.142

Net Cash Flow 5 Rp.4.165.315.618 16.415.636.760

Payback Period $=$ Rp 2.000.000.000 /

1.993.093.534 tahun

$=1.0034652$ tahun

$=1+(0034652 \times 30$ hari

$=1$ tahun 10 hari

Net Present Value (NPV), Perhitungan NPV sangat diperlukan untuk menentukan dan mengetahui apakah dana yang diinvestasikan mengandung resiko yang besar. NPV yang diproyeksikan menggunakan discount Factor $10 \%$ dengan total value 12.041.072.191 dengan modal Rp. 2.000.000.000 maka NPV > 0 .

\section{SIMPULAN}

Berdasarkan hasil penelitian dan pembahasan yang telah dilakukan maka dapat ditarik kesimpulan bahwa berdasarkan analisa aspek pasar dinyatakan layak karena potensi pasar yang ada cukup besar. Berdasarkan analisa aspek operasi rencana usaha ini layak untuk diimplementasikan.

Berdasarkan analisa aspek keuangan rencana usaha ini layak untuk diimplementasikan. Karena NPV > 0 dan Payback Period kurang dari waktu yang diproyeksikan. Berdasarkan analisa aspek sumber daya manusia sumber daya manusia, rencana usaha ini layak untuk diimplemestasikan. Karena ketersediaan tenaga kerja yang kompeten dilokasi usaha akan didirikan. 
Berdasarkan tujuan penelitian dan kesimpulan dari hasil penelitian, maka diajukan beberapa saran adalah Nilai rencana dari investasi ini cukup besar oleh karena itu perlu adanya keseriusan dalam melakukan pengembangan produk baru ini, khusunya menjaga kualitas dan menjalin hubungan yang baik kepada investor dan supplayer bahan baku.

\section{DAFTAR PUSTAKA}

Desri Yesi, 2013, Study kelayakan usaha pemanfaatan limbah kopi untuk pakan kambing di kota pagar alam.

Dini Cahyandari, 2007, Pemanfaatan Limbah Kayu Sebagai Bahan Dasar Pembuatan Papan Partikel.

Fronthea Swastawati, 2011, Studi Kelayakan Dan Efisiensi Usaha Pengasapan Ikan Dengan Asap Cair Limbah Pertanian.

Gitosudarmo, Indriyo, 1999, Manajemen Operasi.

http://www.academia.edu/4631973/

Mengidentifikasi_Faktor_Inte rnal_dan_Eksternal_dengan Analisis_SWOT_pada_Perus ahaan_Konveksi.

http://www.academia.edu/6473904/A nalisis_beban_kerja_dan_keb utuhan_karyawan. http://organisasi.malangkota.go.id/20 14/05/30/penyusunan-analisabeban-kerja/.

http://putri-ckstudy.blogspot.com/2013/01/ beban-kerja-danperhitungannya.html.

http://kelincicoklatdiary.wordpress.c om/2010/10/14/net-presentvalue-npv-dan-internal-rateof-return-irr/

http://salimafarma.blogspot.com/201 1/05/metode-dan-teknikpengumpulan-data.html.

http://www.bglconline.com/2014/09/ kelayakan-bisnis-cost-ofcapital/.

Indrianto, Nur dan Supomo, Bambang, 2009, Metodologi Penelitian Bisnis.

Joko, Sri, 2001, Manajemen Produksi dan Operasi

Joko, Sri, 2004, Manajemen Produksi dan Operasi

Ramadhan Moh. Bambang Gilang, Pemanfaatan Limbah Kayu Untuk Perancangan Casing Produk Information Technology Dengan Pendekatan Konsep Retro

Sutojo, Siswanto, 1993, Study Kelayakan Proyek

Sutojo, Siswanto, 2002, Study

Kelayakan Proyek 